Maciej MIŻEJEWSKI

Uniwersytet Jagielloński

presscd@gmail.com

\title{
KRAJOWA RADA RADIOFONII \\ I TELEWIZJI ORGANEM POLITYCZNEJ KONTROLI NADAWCÓW W POLSCE
}

\begin{abstract}
The National Broadcasting Council as the authority of political control of broadcasters in Poland

According to the Constitution of the Republic of Poland, the National Broadcasting Council: safeguards the freedom of speech, the right to information and the public interest in broadcasting. The protection of these values justifies the independence of the social flow of information in public affairs from the disposal of the government. In the meantime the chairman of the National Broadcasting Council due to his special statutory entitlements remains under exceptional political pressure as in the process of control broadcasters' activity is among others entitled to impose financial sanctions what in fact makes the National Broadcasting Council in Poland the authority that takes actions of repressive censorship nature.
\end{abstract}

Słowa kluczowe: upolitycznienie mediów, polityka medialna, media publiczne

Key-words: politicization of the media, media politics, public media

U chwalona 29 grudnia 1992 r. ustawa o radiofonii i telewizji powołała nowy organ państwowy właściwy w sprawach radiofonii i telewizji, którym zgodnie z art. 5 jest Krajowa Rada Radiofonii i Telewizji ${ }^{1}$. Rada stała się organem konstytucyjnym

Ustawa z dnia 29 grudnia 1992 r. o radiofonii i telewizji, t.j. Dz. U. 2004, nr 253, poz. 2531 z późn. zm., art. 5-12. 
z chwilą uchwalenia Konstytucji RP w 1997 r. Zapisy o KRRiT znalazły się w rozdziale 9 Konstytucji, dotyczącym organów kontroli państwowej i ochrony prawa. Rolę i zadania Krajowej Rady określają bowiem zarówno Konstytucja RP, jak i ustawa o radiofonii i telewizji ${ }^{2}$.

$\mathrm{Z}$ uwagi na swoje kompetencje należy ona do naczelnych organów władzy wykonawczej, choć nie jest organem administracji rządowej. Zgodnie z art. 213 ust. 1 Konstytucji KRRiT stoi na straży wolności stowa, prawa do informacji oraz interesu publicznego $w$ radiofonii i telewizji. Ochrona tych wartości uzasadnia uniezależnienie spotecznego obiegu informacji w sprawach publicznych od dyspozycji rzadu. Dlatego też kontrola obiegu informacji nie może w państwie demokratycznym spoczywać $w$ rękach tego samego organu, który kieruje polityka państwa3.

Zadania omawianego organu konstytucyjnego określa ustawa o radiofonii i telewizji, stanowiąc w art. 6 ust. 1, że poza wolnością słowa w mediach KRRiT stoi na straży samodzielności nadawców i interesów odbiorców, a także zapewnia otwarty i pluralistyczny charakter radiofonii i telewizji $i^{4}$.

Trybunał Konstytucyjny w orzeczeniu z 2006 r. stwierdził, że: KRRiT jest organem konstytucyjnym, postawionym poza schematem trójpodziatu wtadz. Jego wewnętrzna struktura zapewnia, w realizacji konstytucyjnie określonych zadań, równowage między wtadzq ustawodawcza i wykonawcza (Art. 10 Konstytucji). Choćjej zadania w znacznym stopniu wią̇a się z dziatalnościa administracyjno-wykonawcza, to jest usytuowana jak gdyby pomiędzy egzekutywa a legislatywa, przy zachowaniu wyraźnego dystansu wobec rzadu ${ }^{5}$. Wypełnianie zadań w zakresie funkcjonowania mediów elektronicznych niezależnie od rządu jest wręcz „racją istnienia” KRRiT jako szczególnego organu. Łączy się z tym niezależny status i brak formalnego podporządkowania innym organom państwowym, w szczególności autonomiczność w stosunku do Rady Ministrów i jej prezesa.

$\mathrm{Z}$ założenia winno to być ciało apolityczne, co ma zagwarantować sformułowany w art. 214 ust. 2 Konstytucji RP zakaz przynależności członków Rady do partii politycznych i związków zawodowych oraz prowadzenia działalności publicznej niedającej się pogodzić z godnością pełnionej funkcji. Ustawa o radiofonii i telewizji, określając kryteria powoływania członków KRRiT, w art. 7 ust. 1 wspomina jedynie, że mają być wybierani spośród osób wyróżniających się wiedzą i doświadczeniem w zakresie środków spotecznego przekazu.

Konstytucja RP z dnia 2 kwietnia 1997 r., Dz. U. 1997, nr 78, poz. 483, art. 213-215; Ustawa $z$ dnia 29 grudnia 1992 r. o radiofonii i telewizji, art. 5-12.

3 I. Dobosz, Prawo prasowe, Warszawa 2011, s. 118, Seria Akademicka Wolters Kluwer Polska. Zob. też: P. Sarnecki, Regulacja problematyki środków spotecznego przekazu w Konstytucji Rzeczypospolitej Polskiej, [w:] Prawo mediów, red. J. Barta, R. Markiewicz, A. Matlak, Warszawa 2005, s. 31; R. Chruściak, Konstytucjonalizacja wolności mediów, wolności wypowiedzi oraz Krajowej Rady Radiofonii i Telewizji. Ksztattowanie przepisów konstytucyjnych i ustawowych, Warszawa 2004, s. 27-141, Z Prac Instytutu Nauk Politycznych, 10. Studia nad Polityka, 11.

4 A. Matlak, Radiofonia i telewizja, [w:] Prawo mediów, s. 137.

5 Wyrok Trybunatu Konstytucyjnego z dnia 23 marca 2006 r., sygn. akt K 4/06, OTK ZU 2006, nr 3A, poz. 32; L. Garlicki, Polskie prawo konstytucyjne. Zarys wyktadu, wyd. 9, Warszawa 2005, s. 342. 
Uzasadniony z punktu widzenia zasad uniezależnienia członków KRRiT od nadawców jest art. 8 ust. 4 ustawy o radiofonii i telewizji, który zabrania łączenia członkostwa w Radzie z posiadaniem udziałów lub akcji spółki bądź uczestniczenia w inny sposób w podmiocie będącym dostawcą usługi medialnej, producentem radiowym lub telewizyjnym oraz z wszelką działalnością zarobkową z wyjątkiem pracy dydaktyczno-naukowej w charakterze nauczyciela akademickiego lub pracy twórczej ${ }^{6}$.

Niezależności członków KRRiT od zmieniających się układów politycznych ma sprzyjać także tryb ich powoływania, kadencyjność, a zwłaszcza tryb ich odwoływania. Obecnie Rada składa się z pięciu członków powoływanych w następującym trybie: dwóch przez Sejm, jeden przez Senat i dwóch przez prezydenta RP. Członkowie głosują, podejmując uchwały większością dwóch trzecich głosów ustawowej liczby członków (art. 9 ust. 2 ustawy o radiofonii i telewizji), co oznacza, przy nieparzystej liczbie członków, że za uchwałą musi głosować czterech członków, a zatem bez poparcia przedstawiciela prezydenta nie będzie przewagi w Radzie. W procesie powoływania członków KRRiT uwagę zwraca fakt odsunięcia rządu od decydowania o jej składzie.

Kadencja członków trwa sześć lat, bez możliwości powołania na kolejną pełną kadencję. W praktyce są oni nieodwoływalni w trakcie pełnienia funkcji, poza szczególnymi sytuacjami wymienionymi w ustawie. Może to nastąpić wyłącznie w przypadku zrzeczenia się funkcji, choroby trwale uniemożliwiającej jej sprawowanie, skazania prawomocnym wyrokiem za popełnienie przestępstwa z winy umyślnej, złożenia niezgodnego z prawdą oświadczenia lustracyjnego, stwierdzonego prawomocnym orzeczeniem sądu, oraz naruszenia przepisów ustawy stwierdzonego orzeczeniem Trybunału Stanu (art. 7 ust. 6). Organy powołujące członków KRRiT mają także wpływ na dalsze losy tej instytucji. Rada jako jednolity, kolegialny organ konstytucyjny ponosi bezpośrednią odpowiedzialność przed organami, które powołują jej członków: Sejmem, Senatem i prezydentem. Sejm i Senat mogą bowiem przyjąć lub odrzucić w formie uchwał doroczne sprawozdanie KRRiT. W przypadku odrzucenia sprawozdania przez obie izby parlamentu kadencja członków rady wygasa w ciągu 14 dni, chyba że sprzeciwi się temu prezydent (art. 12 ust. 5).

Szczególna rola w tym konstytucyjnym organie państwa przypadła jego przewodniczącemu ${ }^{7}$. Przewodniczący KRRiT (mimo że jest osobnym organem) wybierany jest przez członków rady (art. 7 ust. 2b). Jedynie w takim trybie może też zostać odwołany. Obecny kształt tego przepisu pochodzi z 2006 r. ${ }^{8}$ Gdy KRRiT rozpoczynała działalność, zasada ta jednak nie obowiązywała. Pierwszego przewodniczącego, Marka Markiewicza, desygnował prezydent Lech Wałęsa, co wywołało spory prawne z chwilą, gdy postanowił go odwołać.

$6 \quad$ I. Dobosz, Prawo prasowe, s. 119.

Tamże.

8 Ustawa z dnia 25 kwietnia 2006 r. o zmianie ustawy o radiofonii i telewizji, Dz. U. 2006, nr 83, poz. 574, art. 1.

9 M. Miżejewski, Transformacja telewizji w Polsce po roku 1989 na tle zmian politycznych, Przemyśl 2005, s. 186-187. 
Trybunał Konstytucyjny w uchwale z 10 maja 1994 r. dokonał następującej wykładni art. 7 ust. 2 ustawy, stwierdzając, że: nie może być on rozumiany jako dający uprawnienie do odwotania Przewodniczącego Krajowej Rady, ale opróżnienie tego stanowiska dokonuje się wskutek ustania cztonkostwa $w$ Radzie ${ }^{10}$. Nie powiodła się również próba zmiany tej regulacji z dniem 30 grudnia 2005 r. w postaci zapisu art. 7 ust. 2 ustawy medialnej, stwierdzającego, że Przewodniczącego Krajowej Rady powotuje i odwotuje Prezydent spośród cztonków Krajowej Rady ${ }^{11}$, wprowadzonego ustawą z 20 grudnia 2005 r. o przekształceniach i zmianach w podziale zadań i kompetencji organów państwowych, właściwych w sprawach łączności, radiofonii i telewizji, gdyż taki zapis został uznany przez Trybunał Konstytucyjny za sprzeczny z konstytucją ${ }^{12}$.

Przewodniczący KRRiT posiada bowiem szereg uprawnień ustawowych, stąd jego osoba znajduje się pod szczególną polityczną presją. W opinii Izabeli Dobosz Rada, stojac na straży wolności stowa, dokonuje m.in. monitoringu dziatalności nadawców i podejmuje kroki o charakterze cenzury represyjnej ${ }^{13}$. Przewodniczący może bowiem zażądać od dostawcy usługi medialnej przedstawienia materiałów i dokumentów w zakresie niezbędnym do kontroli zgodności jego działania z przepisami ustawy, warunkami koncesji oraz wiążącymi go aktami samoregulacji. W takim samym zakresie przewodniczący może żądać od nadawcy udzielenia wyjaśnień oraz wezwać go do zaniechania działań, jeśli naruszają one przepisy ustawy, uchwały KRRiT lub warunki wykonywania koncesji.

Przewodniczący może też wydać decyzję nakazującą zaniechania tych działań (do takiej decyzji potrzebna jest jednak uchwała Rady upoważniająca przewodniczącego). Decyzja podlega zaskarżeniu do sądu gospodarczego w Warszawie ${ }^{14}$. W decyzji przewodniczący KRRiT może nałożyć na nadawcę karę pieniężną, której wysokość nie może przekroczyć 50\% rocznej opłaty za używanie częstotliwości, a w przypadku gdy nadawca nie uiszcza opłaty za częstotliwość (nadawca publiczny lub społeczny), kara ta może wynosić do $10 \%$ przychodu nadawcy osiągniętego w poprzednim roku podatkowym, uwzględniając zakres i stopień szkodliwości naruszenia, dotychczasową działalność nadawcy oraz jego możliwości finansowe ${ }^{15}$.

Krajowa Rada Radiofonii i Telewizji pełni też funkcje administracyjne. Ustawa o radiofonii i telewizji wyposaża bowiem KRRiT w prawo podejmowania rozstrzygnięć w sprawach koncesji na rozpowszechnianie i rozprowadzanie programów (art. 6 ust. 2 pkt 3).

Jak wyjaśnił Trybunał Konstytucyjny: KRRiT jest konstytucyjnym organem państwa wyposażonym $w$ szereg istotnych kompetencji, których realizacja (rozstrzygnięcia $w$ formie uchwat $i$ wydawanie decyzji administracyjnych) stanowi element wykonywania przez

10 Uchwata Trybunatu Konstytucyjnego z dnia 10 maja 1994 r., sygn. akt W. 7/94.

11 Ustawa $z$ dnia 29 grudnia 1992 r. o radiofonii i telewizji, art. 7.

12 Wyrok Trybunatu Konstytucyjnego z dnia 23 marca 2006 r., sygn. akt K 4/06.

13 I. Dobosz, Prawo prasowe, s. 120.

14 Ustawa $z$ dnia 29 grudnia 1992 r. o radiofonii i telewizji, art. 56 ust. 1.

15 I. Dobosz, Prawo prasowe, s. 121. 
państwo jego funkcji ${ }^{16}$. Jak zauważono w literaturze $\mathrm{w}$ oparciu o analizę polskiego stanu prawnego w dziedzinie mediów, Krajowa Rada Radiofonii i Telewizji jest [...] organem wtadzy wykonawczej, do tego naczelnym [...] nie jest jednak organem administracji państwowej [...] organ ten nie tylko chroni prawo, lecz również zarządza pewna sfera. stosunków publicznych [...] w ramach konstytucji i ustaw [...] KRRiT samodzielnie administruje, samodzielnie ustala i realizuje, czyli prowadzi polityke państwa ${ }^{17}$. Na mocy przepisu konstytucyjnego (art. 213) KRRiT może wydawać rozporządzenia przewidziane w ustawach i zgodne z zawartymi w nich dyspozycjami, a w sprawach indywidualnych podejmuje uchwały. Nowelizacja ustawy o radiofonii i telewizji z $2010 \mathrm{r}$. powiększyła zakres jej odpowiedzialności za realizację misji mediów publicznych, wyposażając ją w nowe kompetencje w zakresie powoływania władz tych mediów oraz finansowania ich z opłat abonamentowych.

Pewną autonomię Krajowa Rada Radiofonii i Telewizji posiada także wobec organów powołujących jej członków - Sejmu, Senatu, prezydenta - z uwagi na to, że ustawa o radiofonii i telewizji nie łączy kadencji członków KRRiT z kadencjami żadnego z tych organów. KRRiT nie jest więc związana z konkretnym składem parlamentu czy osobą prezydenta ${ }^{18}$. Do zadań Krajowej Rady Radiofonii i Telewizji należy projektowanie w porozumieniu z prezesem Rady Ministrów kierunków polityki państwa w dziedzinie radiofonii i telewizji (art. 6 ust. 2 ustawy o radiofonii i telewizji).

Zgodnie z ustawą z 4 września 1997 r. o działach administracji rządowej polityka audiowizualna znajduje się we właściwości ministra kultury i dziedzictwa narodowego $^{19}$. Opracowany i przyjęty całościowy dokument określający politykę audiowizualną państwa i priorytety w tej dziedzinie będzie dla Krajowej Rady Radiofonii i Telewizji zbiorem wytycznych o charakterze strategicznym. KRRiT uczestniczy w pracach strategicznych rządu w zakresie określania polityki audiowizualnej i strategii rozwoju kapitału społecznego, strategii cyfryzacji mediów publicznych i ich finansowania.

Krajowa Rada Radiofonii i Telewizji nie posiada inicjatywy ustawodawczej. Jedynie opiniuje, na zlecenie rządu i Sejmu, projekty aktów ustawodawczych oraz umów międzynarodowych dotyczących radiofonii i telewizji (art. 6 ust. 7 ustawy o radiofonii i telewizji). KRRiT wnosi również wkład do prac rządu związanych z współtworzeniem i implementacją europejskiej polityki audiowizualnej ${ }^{20}$ oraz działalnością w organizacjach międzynarodowych.

16 Wyrok Trybunatu Konstytucyjnego $z$ dnia 23 marca 2006 r., sygn. akt K 4/06.

17 Prawo mediów, s. 29-30.

18 Uchwata Trybunatu Konstytucyjnego z dnia 10 maja 1994 r., sygn. akt W. 7/94; Wyrok Trybunatu Konstytucyjnego $z$ dnia 23 marca 2006 r., sygn. akt K 4/06.

19 Ustawa z dnia 4 września 1997 r. o dziatach administracji rządowej, Dz. U. 2007, nr 65, poz. 437, art. 14 ust. 1 pkt 9 .

20 W pierwszej połowie 2011 r. Rada przedstawiła Sejmowi i rządowi propozycje legislacyjne związane z ówczesnym projektem nowelizacji ustawy o radiofonii i telewizji służącym transpozycji dyrektywy $\mathrm{o}$ audiowizualnych usługach medialnych. 
KRRiT opracowuje także własne dokumenty strategiczne ${ }^{21}$ wyrażające założenia, cele i kierunki polityki tego konstytucyjnego organu państwa w dziedzinie mediów elektronicznych. Przykładem tego jest m.in. Strategia regulacyjna na lata 2011-2013. Własne prace analityczne Krajowej Rady Radiofonii i Telewizji pokazują bowiem, że procesy zachodzące $w$ mediach elektronicznych wymagają szybkiej i wszechstronnej zmiany regulacji prawnej, w pełni odpowiadającej nowym warunkom działania mediów elektronicznych i umożliwiającej realizowanie celów polityki publicznej w tej dziedzinie.

Ponadto KRRiT przedstawia premierowi informację o koniecznych zmianach prawnych w zakresie ustaw regulujących działalność nadawców radiowych i telewizyjnych, zapoznając prezesa Rady Ministrów z opiniami i stanowiskami KRRiT, które mają wpływ na stan rynku mediów elektronicznych w Polsce, w postaci dorocznej „Informacji o podstawowych problemach radiofonii i telewizji”.

Krajowa Rada Radiofonii i Telewizji jest także współodpowiedzialna za zapewnienie technicznych możliwości rozwoju środków masowego komunikowania. W ramach tej współodpowiedzialności dba, aby dla potrzeb radiodyfuzji zabezpieczyć odpowiednie zakresy częstotliwości. Przeznaczenie poszczególnych zakresów częstotliwości dla danych służb wynika z polskiej Tablicy Przeznaczeń Częstotliwości zawartej w rozporządzeniu Rady Ministrów z 29 czerwca 2005 r. ${ }^{22}$

Prezes Urzędu Komunikacji Elektronicznej (UKE) ma uprawnienia bezpośrednio związane z wykonywaniem ustawowych zobowiązań przez KRRiT w zakresie prowadzenia postępowań koncesyjnych ${ }^{23}$. Przepisy ustawy o radiofonii i telewizji oraz prawa telekomunikacyjnego określają pola współpracy między KRRiT a UKE ${ }^{24}$. Ustawa o wdrożeniu naziemnej telewizji cyfrowej przewiduje czynny udział KRRiT w tym procesie $^{25}$. Rada aktywnie uczestniczy we wszystkich pracach związanych z cyfrową konwersją telewizji naziemnej, opracowaniem koncepcji zagospodarowania multipleksów oraz

21 Są to takie dokumenty, jak Dziatalność Krajowej Rady Radiofonii i Telewizji w zakresie wprowadzania naziemnej telewizji cyfrowej w Polsce, Warszawa 2006; Obrona lokalności i demokracji lokalnej. Strategia dziatania Krajowej Rady Radiofonii i Telewizji na rzecz ochrony lokalnego charakteru i pluralizmu oferty programowej w lokalnych mediach elektronicznych, Warszawa 2005; Strategia Państwa Polskiego $w$ dziedzinie mediów elektronicznych na lata 2005-2020, Warszawa 2005; Biata ksiega „Polityka państwa polskiego w dziedzinie mediów elektronicznych w kontekście europejskiej polityki audiowizualnej - zatożenia nowej ustawy o mediach elektronicznych”, Warszawa 2004; Zielona ksiega „Polityka państwa polskiego $w$ dziedzinie mediów elektronicznych w kontekście europejskiej polityki audiowizualnej zatożenia nowej ustawy o mediach elektronicznych", Warszawa 2003.

22 Rozporządzenie Rady Ministrów z dnia 29 czerwca 2005 r. w sprawie Krajowej Tablicy Przeznaczeń Częstotliwości, Dz. U. 2005, nr 134, poz. 1127 z późn. zm.

23 I. Dobosz, Prawo prasowe, s. 129-130.

24 Ustawa z dnia 16 lipca 2004 r. Prawo telekomunikacyjne, Dz. U. 2004, nr 171, poz. 1800 z późn. zm., art. 115-122, zmieniona Ustawa $z$ dnia 29 grudnia 2005 r. o przeksztatceniach i zmianach $w$ podziale zadań $i$ kompetencji organów państwowych wtaściwych w sprawach taczności, radiofonii i telewizji, Dz. U. 2005, nr 267, poz. 2258. Ustawa ta zniosła dotychczasowy Urząd Regulacji Telekomunikacji i Poczty, zastępując go Urzędem Komunikacji Elektronicznej.

25 Ustawa $z$ dnia 30 czerwca 2011 r. o wdrożeniu naziemnej telewizji cyfrowej, Dz. U. 2011, nr 153, poz. 903. 
uruchomieniem telewizji mobilnej, a także w pracach koncepcyjnych związanych z cyfryzacją radia, współpracując w tym zakresie z Urzędem Komunikacji Elektronicznej.

Historia tej współpracy wskazuje na poważne trudności wynikające z przyjmowanych przez oba organy różnych stanowisk w zakresie regulacji sektora audiowizualnego. W sferze konwersji cyfrowej niektóre najistotniejsze przeszkody może usunąć ustawa o wdrożeniu naziemnej telewizji cyfrowej, nie rozwiązuje ona jednak wszystkich problemów dotyczących nadawania cyfrowego w telewizji. Obecnie przepisy prawa telekomunikacyjnego przewidują, że uzgadnianie warunków konkursu na operatora multipleksu, a także zmiany i cofanie decyzji rezerwacyjnych wydanych w efekcie przeprowadzenia tego konkursu są dokonywane w trybie kodeksu postępowania administracyjnego ${ }^{26}$. Należy dodać, że w projekcie założeń do zmiany ustawy Prawo telekomunikacyjne proponuje się powrót do uzgodnień w tym względzie z przewodniczącym KRRiT.

Artykuł 118 ust. 5 prawa telekomunikacyjnego określa szczegółowe warunki konkursu na operatora multipleksu, przy czym warunki uczestnictwa w zakresie zawartości programowej (w tym m.in. transmisji obowiązkowej) określa KRRiT na wniosek prezesa UKE, uwzględniając pozaekonomiczne interesy narodowe dotyczące kultury, języka i pluralizmu mediów ${ }^{27}$.

\section{ROLA KRAJOWEJ RADY RADIOFONII I TELEWIZJI W DZIEDZINIE OCHRONY PLURALIZMU MEDIÓW}

Zgodnie z art. 36 ust. 2 pkt 2 ustawy o radiofonii i telewizji koncesji na rozpowszechnianie programu radiowego lub telewizyjnego nie udziela się, jeżeli rozpowszechnianie programów przez wnioskodawcę mogłoby spowodować m.in. osiagnięcie przez wnioskodawce pozycji dominujacej $w$ dziedzinie środków masowego przekazu na danym terenie. Z dotychczasowych doświadczeń Krajowej Rady Radiofonii i Telewizji wynika, że obecny kształt przepisów (w tym brak definicji przejęcia kontroli nad działalnością nadawcy oraz pozycji dominującej odpowiedniej dla rynku mediów oraz brak przepisów umożliwiających zebranie przez przewodniczącego KRRiT niezbędnych informacji od przedsiębiorców do przeprowadzenia analizy koncentracji i zachowania warunków konkurencji) uniemożliwia skuteczne przeciwdziałanie niekorzystnym zjawiskom zagrażającym pluralizmowi opinii i źródeł informowania. Dotyczy to w szczególności rynku radiowego, na którym zjawisko koncentracji kapitałowej (poprzez tzw. spinanie sieci) w istotny sposób wpływa na zubożenie i unifikację programów lokalnych.

Jeszcze poważniejszą przeszkodę stanowi różnica logik i celów przyświecających prawu konkurencji oraz regulacji medialnej. Celem prawa konkurencji ${ }^{28}$ jest dbanie

26 Ustawa z dnia 14 czerwca 1960 r. Kodekspostępowania administracyjnego, Dz. U. 2000, nr 98, poz. 1071 z późn. zm., art. 106

27 Ustawa $z$ dnia 16 lipca 2004 r. Prawo telekomunikacyjne.

28 Ustawa z dnia 16 kwietnia 1993 r. o zwalczaniu nieuczciwej konkurencji, t.j. Dz. U. 2003, nr 153, poz. 1503 z późn. zm. 
o właściwe funkcjonowanie wolnego rynku, a co się z tym wiąże - wolnej konkurencji między podmiotami rynkowymi. Nadrzędnym celem przepisów ograniczających koncentrację własności w mediach jest natomiast zachowanie pluralizmu mediów. Pluralizm jest bowiem naturalnym wrogiem wolnego rynku.

Zgodnie z ustawą o ochronie konkurencji i konsumentów przedsiębiorca posiada pozycję dominująca, która umożliwia mu zapobieganie skutecznej konkurencji na rynku wtaściwym, jeżeli ma możliwość dziatania w znacznym zakresie niezależnie od konkurentów, kontrahentów i konsumentów (nie jest niedozwolone posiadanie pozycji dominującej, ale jej nadużywanie). Domniemywa się, że przedsiębiorca ma pozycje dominująca, jeżeli jego udziat w rynku przekracza $40 \%^{29}$. Z kolei przepis art. 36 ust. 2 pkt 2 ustawy o radiofonii i telewizji wyraźnie odnosi pozycje dominująca na danym terenie do całej dziedziny środków masowego komunikowania, co obejmuje nie tylko dysponowanie na niej stacją radiową, telewizyjną, ale też np. gazetą ${ }^{30}$. Jeżeli więc udział takiego podmiotu w każdym z tych osobnych rynków nie powoduje osiągnięcia pozycji dominującej, a więc nie przekracza 40\%, ustawa o ochronie konkurencji i konsumentów nie ma zastosowania - choć w sumie podmiot ten może pośrednio lub bezpośrednio kontrolować większość informacji i opinii publikowanych w mediach na danym terenie i jego dotyczących.

Jeżeli więc przepis art. 36 ust. 2 ustawy o radiofonii i telewizji ma znaleźć praktyczne zastosowanie, wymagane są zmiany w prawie. Rozporządzenie Rady Unii Europejskiej w sprawie kontroli koncentracji między przedsiębiorstwami stwierdza, że państwa członkowskie mogą podejmować działania inne niż przewidziane w rozporządzeniu m.in. na rzecz pluralizmu mediów ${ }^{31}$. Zgodnie więc z tezą przedstawioną w Zielonej księdze $e^{32}$ i podtrzymaną w Biatej księdze $e^{33}$ zapewnienie pluralizmu mediów to sfera polityki państw członkowskich, a prawo wspólnotowe dopuszcza przepisy krajowe majace chronić pluralizm medió $w^{34}$.

29 Ustawa z dnia 16 lutego 2007 r. o ochronie konkurencji i konsumentów, Dz. U. 2007, nr 50, poz. 331, art. 4.

30 Ponadto w dokumencie UE pt. Zielona ksiega nt. ustug użyteczności publicznej, $\operatorname{COM(2003)~} 270$ czytamy, że dziatania na rzecz pluralizmu mediów zazwyczaj zmierzają do ograniczenia udziatów $w$ przedsiębiorstwach medialnych lub do zapobieżenia kumulacyjnej kontroli lub jednoczesnemu udziatowi w kilku przedsiębiorstwach medialnych.

31 Rozporzadzenie Rady (WE) nr 139/2004 z dnia 20 stycznia 2004 r. w sprawie kontroli koncentracji przedsiębiorstw, Dz. U. UE L 24, 29 I 2004, art. 21 ust. 4.

32 Zielona ksiega "Pluralizm i koncentracja mediów w ramach rynku wewnętrznego - ocena potrzeb dziatania na szczeblu Wspólnotowym”, Bruksela, 23.12.1992, COM(92) 480.

33 Komunikat Komisji do Parlamentu Europejskiego, Rady, Komitetu Ekonomiczno-Spotecznego oraz Komitetu Regionów - Biata ksiega nt. ustug użyteczności publicznej, Bruksela, 12.5.2004, COM(2004) 374 wersja ostateczna.

34 Wypowiadając się w tej kwestii w 2001 r., Mario Monti, wówczas członek Komisji Europejskiej, wskazał, że uzasadnione zaniepokojenie może budzić również koncentracja mediów w sytuacji, gdy sita rynkowa poszczególnych podmiotów nie osiagnęta skali, która wymagataby zastosowania przepisów oochroniekonkurencji. W takich przypadkach przepisy antymonopolowemoga okazaćsięniewystarczające, aby zapewnić pluralizm mediów. Wtedy państwa cztonkowskie dysponuja swoboda wprowadzenia 
W realizacji ustawy o radiofonii i telewizji należy więc posiłkowo sięgać do analogii z ustawą o ochronie konkurencji i konsumentów w zakresie definicji pozycji dominującej, ale zgodnie z ustawą o radiofonii i telewizji odnosić ją do całej dziedziny środków masowego komunikowania na danym terenie, a nie do rynku właściwego w rozumieniu prawa antymonopolowego. Należy też rozważyć, wzorem niektórych krajów unijnych, wprowadzenie przepisów nakazujących przy ocenie dopuszczalności fuzji i przejęć na rynku medialnym stosowanie testu interesu publicznego, pozwalającego ocenić wpływ zmiany własnościowej na pluralizm mediów na danym rynku, nawet jeżeli nie doszło do przekroczenia dopuszczalnych progów pozycji rynkowej. Pozwoliłoby to zapobiegać fuzjom i przejęciom o szkodliwym wpływie na działalność mediów. Stosuje się też dokonywanie przez regulatora audiowizualnego na wniosek urzędu ds. ochrony konkurencji oceny lokalnego rynku mediów w celu sprawdzenia, czy konkretna fuzja medialna zagraża swobodzie konkurencji na nim, czy nie.

Według opinii KRRiT, przedstawionej w Strategii regulacyjnej na lata 2011-2013³5, należałoby ponadto rozważyć fuzje i przejęcia oraz charakter relacji ekonomicznych w sektorze reklamy, ściśle powiązanym z sektorem mediów. Działalność domów mediowych, hurtowy zakup czasu antenowego oraz praktyki dyktatu cenowego nie należą w tej dziedzinie do rzadkości. W istocie ograniczają one pluralizm i nie sprzyjają finansowaniu nowych przedsięwzięć. Przedmiotem szczególnego nadzoru powinni stać się także operatorzy telewizji kablowej i platform cyfrowych, ich działania często bowiem blokują rozwój rynku. Orzecznictwo antymonopolowe wskazuje, że właśnie w tej dziedzinie najczęściej stosowane są tzw. klauzule niedozwolone.

Troska o pluralizm mediów wymaga także m.in.:

- świadomego zaplanowania i wykorzystania procesu konwersji cyfrowej w celu zwiększenia pluralizmu właścicielskiego oraz aktywnej polityki regulacyjnej mających zapewnić pełny pluralizm strukturalny i programowy oferty ${ }^{36}$;

- wzmocnienia regionalnego i lokalnego charakteru programu stacji regionalnych i lokalnych (w tym analizy źródeł finansowania stacji lokalnych, łącznie z kwestią dostępu do rynku reklamy);

- zapewnienia misyjnego charakteru i właściwego finansowania mediów publicznych oraz ich zdolności do właściwego wykonywania swoich zadań, w tym przez zawieranie porozumień co do planów finansowo-programowych gwarantujących pluralizm oferty programowej.

Zgodnie z wymogami Unii Europejskiej państwa członkowskie mają obowiązek poddać „ważne nowe usługi audiowizualne” nadawców publicznych tzw. testowi amsterdamskiemu (na zgodność usługi z wymogami protokołu amsterdamskiego, tj. czy

dodatkowych przepisów. W celu ochrony pluralizmu mediów moga one nawet zapobiegać fuzjom, które zostatyby zatwierdzone przy zastosowaniu jedynie przepisów o ochronie konkurencji - cyt. za: Media Diversity in Europe, Media Division, Directorate General of Human Rights, Strasbourg 2002.

35 Krajowa Rada Radiofonii i Telewizji, Strategia regulacyjna na lata 2011-2013, Warszawa 2011.

36 O ile wśród analogowych programów telewizyjnych w krajach unijnych programy publiczne stanowią ok. $10 \%$, na platformach naziemnej telewizji cyfrowej stanowią - wskutek takiej właśnie polityki regulacyjnej - ponad $26 \%$. 
spełniają demokratyczne, społeczne i kulturalne potrzeby społeczeństwa) oraz ocenie ogólnego ich oddziaływania na rynek ${ }^{37}$. Krajowa Rada Radiofonii i Telewizji będzie samodzielnie przeprowadzała test amsterdamski (także w ramach procedury koncesyjnej, gdy rozpatrywać będzie wnioski o udzielenie koncesji nowym programom specjalistycznym nadawców publicznych).

Radiofonia i telewizja są rynkiem regulowanym, stąd do zadań Rady należy:

- reglamentacja dostępu do możliwości rozpowszechniania programu (proces koncesyjny, przyznawanie kanałów w multipleksach);

- regulacja strukturalna (decydowanie w ramach polityki koncesyjnej o tym, jakie typy nadawców mają być obecne na rynku);

- regulacja behawioralna (określanie warunków wykonywania koncesji oraz wydawanie rozporządzeń nakazujących lub zakazujących określonych praktyk dostawcom zawartości).

W toku postępowania o udzielenie koncesji ocenia się w szczególności stopień zgodności zamierzonej działalności programowej z zadaniami określonymi w art. 1 ust. 1 ustawy o radiofonii i telewizji z uwzględnieniem stopnia realizacji tych zadań przez innych nadawców działających na obszarze objętym koncesją. Kierując się tą przesłanką, Krajowa Rada Radiofonii i Telewizji dokonuje wyboru przyszłego koncesjonariusza, biorąc pod uwagę innowacyjność i oryginalność jego oferty programowej oraz zaprezentowany sposób realizacji programu.

Wzbogacenie istniejącej oferty programowej na danym obszarze jest jednym z głównych kryteriów wyboru w postępowaniu o udzielenie koncesji. Zróżnicowanie to może wyrażać się poprzez skierowanie programu do określonej grupy odbiorców, ewentualnie wskazanie wiodącej tematyki lub formatu muzycznego, nieobecnych w nadawanych już na danym obszarze programach.

KRRiT odgrywa ponadto istotną rolę w tworzeniu regionalnych i lokalnych usług medialnych. Pluralizm geograficzny w radiofonii i telewizji jest niedostatecznie rozwinięty, wskutek czego mieszkańcy wielu terenów pozbawieni są pełnowartościowych lub w ogóle jakichkolwiek lokalnych programów radiowych i telewizyjnych ${ }^{38}$. Przyjęty przez Radę Ministrów Plan wdrażania telewizji cyfrowej w Polsce ${ }^{39}$ stwierdza, że trans-

Komisja Europejska, Komunikat Komisji w sprawie stosowania zasad pomocy państwa wobec radiofonii i telewizji publicznej, Dz. U. UE C 257/1, 27 X 2009.

38 W opinii KRRiT stan ten trudno uznać za właściwy czy zgodny z projektem rządowej Strategii rozwoju kapitatu spotecznego (SRKS), która ma realizować następujące cele strategiczne: „Rozwój i efektywne wykorzystanie potencjału kulturowego i kreatywnego”, „Zwiększenie partycypacji obywateli w życiu publicznym i społecznym”, „Poszerzenie przestrzeni dla wysokiej jakości aktywnej komunikacji społecznej i medialnej". W ramach tego ostatniego celu wymienia się m.in. następujące cele operacyjne: wspieranie udziału mediów w kształtowaniu więzi społecznych i demokracji oraz poszerzenie domeny publicznej; zapewnienie powszechnego dostępu do usług medialnych i zapobieganie wykluczeniu cyfrowemu. Zob. też: Krajowa Rada Radiofonii i Telewizji, Obrona lokalności i demokracji lokalnej...

39 Plan wdrażania telewizji cyfrowej w Polsce, Warszawa, 4 VI 2010, [online] http://static.cyfryzacja.gov. $\mathrm{pl} /$ files/documenty/PlanDTTwersja221042010RMRCL.pdf, 15 III 2013. Zob. też: Ustawa z dnia 30 czerwca 2011 o wdrożeniu naziemnej telewizji cyfrowej. 
misja cyfrowa umożliwia m.in. zwiększenie udziatu nadawców lokalnych i możliwości rozwoju regionalnej oferty ${ }^{40}$. W planie stwierdza się też, że realizując cele programowe, należy także zwrócić uwage na konieczność zapewnienia możliwości rozpowszechniania programów poświęconych tematyce regionalnej i lokalnej. Różnorodność geograficzna, odzwierciedlająca życie spoteczności lokalnych oraz zawierająca treści i elementy kultury regionalnej, jest jednym $z$ ważniejszych warunków zachowania pluralizmu mediów. [...] $W$ ramach oferty cyfrowej moga się również znaleźć programy tworzone przez tzw. media "trzeciego sektora”, tj. media środowiskowe ${ }^{41}$.

W dokumencie tym czytamy, że w planowaniu pokryć cyfrowych dążý się będzie do dokonania takiego podziatu obszarów rezerwacji częstotliwości, który odpowiadatby potrzebom spoteczności lokalnych oraz zapewniat nadawcom możliwości finansowania produkcji i emisji programów z przychodów pochodzacych z lokalnych i regionalnych rynków reklamowych ${ }^{42}$.

$\mathrm{Na}$ mocy art. 6 ust. 2 pkt 3a ustawy o radiofonii i telewizji do decyzji Krajowej Rady Radiofonii i Telewizji należy uznanie danego podmiotu za nadawcę społecznego. W trosce o ochronę pluralizmu Rada proponuje, aby pojęciem tym objąć także podmioty tzw. trzeciego sektora, działające non-profit, by realizować w programie wszelkie niekomercyjne cele społeczne, kulturalne, edukacyjne, religijne, charytatywne itp., bez względu na typ własności: stowarzyszenia i fundacje, instytucje kultury itp. KRRiT będzie więc przedstawiać propozycje form wsparcia dla tych nadawców, np. przez uwzględnienie w projektowanych ogłoszeniach o możliwości uzyskania koncesji tego, że wnioskodawca będzie lub jest nadawcą społecznym. W opinii Rady należy rozważyć (uwzględniając konsekwencje wysokości opłaty za wykorzystanie częstotliwości) ewentualne dopuszczenie reklam w ich programach, w bardzo ograniczonym zakresie, z zastrzeżeniem, że wszelkie przychody z tego źródła będą przeznaczone wyłącznie na działalność programową nadawcy. Przetrwanie i rozwój tych nadawców uzależnione są bowiem od uwzględnienia ich w planach konwersji cyfrowej i w podziale kanałów w multipleksach, a zwłaszcza zagospodarowaniu tzw. „dywidendy cyfrowej”, co w opinii Rady bez wątpienia wpłynie na rozwój działalności nadawców społecznych, a w konsekwencji na zwiększenie pluralizmu.

Przygotowanie projektu ustawy transponującej do polskiego prawa dyrektywę Parlamentu Europejskiego i Rady 2010/13/UE z dnia 10 marca 2010 r. zmieniającej dyrektywę Rady 89/552/EWG w sprawie koordynacji niektórych przepisów ustawowych, wykonawczych i administracyjnych państw członkowskich, dotyczących wykonywania telewizyjnej działalności transmisyjnej, było zadaniem Ministerstwa Kultury i Dziedzictwa Narodowego. Przyjęta koncepcja transpozycji poprzez nowelizację ustawy o radiofonii i telewizji uczyniła Krajową Radę Radiofonii i Telewizji gwarantem odpowiedzialnym za zapewnienie przestrzegania nowo wprowadzanych przepisów ${ }^{43}$.

40 Plan wdrażania..., s. 6.

41 Tamże, s. 18.

42 Tamże.

43 Dyrektywa ParlamentuEuropejskiegoi Rady2010/13/UEzdnia 10 marca2010 r.w sprawiekoordynacji niektórych przepisów ustawowych, wykonawczych i administracyjnych państw członkowskich dotyczących świadczenia audiowizualnych usług medialnych (dyrektywa o audiowizualnych usługach medialnych), Dz. U. UE L 95, 15 IV 2010. 
Z tego względu KRRiT uczestniczyła w przygotowaniu procesu wdrożenia dyrektywy na wszystkich dotychczasowych etapach prac, rozpoczynając od przeprowadzenia w 2008 r. konsultacji społecznych, a kończąc na współpracy z Ministerstwem Kultury i Dziedzictwa Narodowego w opracowywaniu ostatecznego projektu ustawy implementacyjnej i jego opiniowaniu podczas prac organów Rady Ministrów oraz parlamentarnych prac legislacyjnych.

Jeszcze w 2008 r. podczas próby nowelizacji ustawy medialnej rząd zaproponował odebranie Krajowej Radzie Radiofonii i Telewizji jednej z najważniejszych kompetencji, a mianowicie przyznawania koncesji nadawcom, i przekazanie tego uprawnienia organowi administracji rządowej, Urzędowi Komunikacji Elektronicznej ${ }^{44}$. W stanowisku przesłanym wówczas marszałkowi Sejmu przewodniczący Krajowej Rady Radiofonii i Telewizji oświadczył, że oddanie kompetencji w sprawach koncesji na rzecz prezesa Urzędu Komunikacji Elektronicznej jest sprzeczne z art. 213 Konstytucji RP, zgodnie $z$ którym Krajowa Rada Radiofonii $i$ Telewizji stoi na straży wolności stowa, prawa do informacji oraz interesu publicznego $w$ radiofonii $i$ telewizji $i^{45}$. Procedura przyznawania koncesji mediom elektronicznym jak najbardziej mieści się w pojęciu interesu publicznego w radiofonii i telewizji. Stanowi to bowiem wyraz troski państwa w zakresie ochrony pluralizmu w mediach.

Propozycja rządzącej koalicji okazała się także sprzeczna z zaleceniem Komitetu Ministrów Rady Europy, które mówiąc o niezależności i funkcji organów regulacyjnych dla sektora usług nadawczych, jednoznacznie wskazuje, że nie powinny być one organami administracji rządowej ${ }^{46}$. Przyznawanie koncesji nadawcom w Polsce przez organ administracji rządowej byłoby więc sprzeczne ze standardami Unii Europejskiej, gdyż nie służyłoby urzeczywistnianiu idei pluralizmu medialnego i tworzyłoby niebezpieczną praktykę podporządkowania mediów władzy ${ }^{47}$.

W kolejnym projekcie nowelizacji ustawy o radiofonii i telewizji, złożonym przez rządzącą koalicję w 2009 r. ${ }^{48}$, zakładającym m.in. likwidację od 1 stycznia 2010 r. abonamentu radiowo-telewizyjnego, Telewizja Polska i Polskie Radio miały być finansowane z Funduszu Zadań Publicznych, którego środki pochodziłyby z budżetu KRRiT. Działalność KRRiT zgodnie z art. 11 ust. 3 ustawy o radiofonii i telewizji jest finansowana z budżetu państwa, stąd też takie rozwiązanie mogłoby dopro-

44 Ustawa z dnia 29 grudnia 1992 r. o radiofonii i telewizji, art. 33.

45 Stanowisko KRRiT, dotyczace poselskiego projektu ustawy o zmianie ustawy o radiofonii $i$ telewizji $i$ innych ustaw, zawartego w druku sejmowym nr 151, przekazane Marszatkowi Sejmu RP 21 stycznia 2008 roku, [online] http://www.krrit.gov.pl/dla-mediow-i-analitykow/publikacje/stanowiska/2008/, 15 III 2013.

46 Zalecenie REC(2000)23 z 20 grudnia 2000 r. Komitetu Ministrów Rady Europy w sprawie niezależności i funkcji organów regulacyjnych dla sektora usług nadawczych wraz z memorandum wyjaśniającym.

47 Obowiązujące obecnie prawne podstawy procedury koncesyjnej w świetle ustawy o radiofonii i telewizji, prawa telekomunikacyjnego oraz orzecznictwa Naczelnego Sądu Administracyjnego analizuje: I. Dobosz, Prawo prasowe, s. 129-143.

48 Projekt ustawy o zadaniach publicznych w dziedzinie usług medialnych, Sejm Rzeczypospolitej Polskiej, druk nr 1847, Warszawa, 18 III 2009. 
wadzić do pełnej zależności finansowej nadawców od władzy, a w konsekwencji do ich pełnej politycznej lojalności.

Zgodnie z projektem skład Krajowej Rady Radiofonii i Telewizji miał zostać rozszerzony z obecnych pięciu do siedmiu członków. Trzech z nich miał powoływać Sejm, dwóch Senat i dwóch prezydent Rzeczypospolitej. Członkowie mieli być wymieniani rotacyjnie: desygnowani przez Sejm co dwa lata, a rekomendowani przez Senat i prezydenta co trzy.

Projekt przewidywał dwuletnie licencje programowe, przyznawane przez KRRiT, które miały określać zadania programowe dla nadawców, finansowane z Funduszu Zadań Publicznych. O licencję mogliby się także ubiegać nadawcy komercyjni, którzy chcieliby tworzyć programy misyjne. Zmienić miała się także struktura organizacyjna Telewizji Polskiej. Projekt ustawy medialnej zakładał decentralizację oddziałów terenowych przez powołanie szesnastu regionalnych spółek telewizyjnych.

Opozycja skrytykowała projekt, traktując go jako próbę przejęcia mediów publicznych przez ugrupowania rządzącej koalicji i podzielenie się w niej partyjnymi wpływami z pominięciem opozycji. Krytycznie do projektu odniósł się też Karol Jakubowicz, twierdząc, że projekt zwiększa koszty funkcjonowania mediów publicznych, nie zapewnia im właściwego finansowania i skazuje w efekcie na stopniową komercjalizację lub upadek. Jakubowicz zarzucił też projektowi, że mechanizmy podporządkowania mediów publicznych rządowi są w nim znacznie wyraźniejsze niż dotychczas ${ }^{49}$.

W 2010 r. do Sejmu trafił kolejny projekt ustawy medialnej, którego autorami byli wybitni polscy twórcy z Andrzejem Wajdą na czele. Projekt twórców był reakcją na wieloletnie upartyjnienie, postępującą komercjalizację i niegospodarność w publicznych mediach ${ }^{50}$. Projekt ustawy medialnej całkowicie zmieniał sposób zarządzania mediami publicznymi. Według zapisów projektu media publiczne nie miały być spółkami skarbu państwa, a państwowymi osobami prawnymi, nie podlegałyby więc regulacjom przepisów kodeksu spółek handlowych ${ }^{51}$. Projekt twórców zakładał zniesienie abonamentu i zastąpienie go tzw. opłatą audiowizualną, na wzór francuskiej redevance audiovisuelle, płaconą wraz z PIT-em. Miałoby to finansowo i programowo uniezależnić media publiczne od rządzących polityków. Projekt pozbawiał Krajową Radę Radiofonii i Telewizji wpływu na publiczne środki masowego komunikowania, odbierając jej m.in. prawo wyboru rad nadzorczych telewizji publicznej ${ }^{52}$.

Propozycja Komitetu Obywatelskiego Mediów Publicznych zakładała stworzenie 250-osobowego Kolegium Elektorskiego, złożonego z osób zgłoszonych m.in. przez

49 Debata „Media publiczne - nowy ład”, Fundacja Batorego, 20 IV 2009, [online] http://www.batory. org.pl/programy_operacyjne/debaty/2009/media_publiczne_nowy_lad, 15 III 2013.

50 Pytanie o media, Wiara.pl, 14 V 2010, [online] http://info.wiara.pl/doc/521755.Pytanie-o-media, 15 III 2013.

51 Pełny tekst projektu na: http://audiowizualni.pl/images/zalaczniki/Ustawa_medialna/projekt_ ustawy_media_publiczne_7.05.10.pdf, 15 III 2013.

52 A. Kublik, Telewizja twórców gotowa, Wyborcza.pl, 4 III 2010, [online] http://wyborcza.pl/ 1,76842,7623630,Telewizja_tworcow_gotowa.html, 15 III 2013. 
organizacje pozarządowe, konferencje rektorów szkół wyższych, organizacje twórców i dziennikarzy oraz samorządy lokalne. $\mathrm{Z}$ tego gremium losowo miał być wyłaniany 50-osobowy Komitet Mediów Publicznych, który z kolei w konkursie miał wybierać 7-osobową Radę Mediów Publicznych.

Rada Mediów Publicznych przez pięcioletnią kadencję stałaby na straży niezależności mediów, określałaby ich obowiązki, uchwalałaby kodeks etyki mediów i rozliczałaby nadawców publicznych z wydawanych pieniędzy. Rada wybierałaby w drodze konkursu dyrektorów telewizji, radia oraz nowo utworzonej instytucji - portalu mediów publicznych, w którym na użytek prywatny dostępne byłyby archiwa nadawców publicznych dla osób opłacających opłatę audiowizualną.

Obawy polityków koalicji budził fakt, że Rada Mediów Publicznych byłaby organem niepodlegającym żadnej kontroli zewnętrznej. W obowiązującym obecnie stanie prawnym Krajowa Rada Radiofonii i Telewizji jest organem konstytucyjnym, nad jej działalnością kontrolę sprawuje parlament oraz prezydent RP, a więc organy powołujące jej członków.

\section{PODSUMOWANIE}

Potwierdzeniem tezy zawartej w tytule artykułu, opisującego pozycję ustrojową oraz praktykę działania KRRiT jako organu politycznej kontroli nadawców, są następujące fakty:

1) Członkowie Krajowej Rady nominowani są przez obie izby parlamentu oraz prezydenta RP zgodnie z regułą politycznego parytetu. Pochodzą więc z wyboru politycznego, choć formalnie art. 214 ust. 2 Konstytucji RP zakazuje przynależności jej członków do partii politycznych czy związków zawodowych. Ustawa o radiofonii i telewizji nie określa ani poziomu wykształcenia, ani wieku kandydatów, stanowi jedynie, że członkowie Rady mają się rekrutować spośród osób wyróżniających się wiedzq̨ i doświadczeniem w zakresie środków spotecznego przekazu (art. 7 ust. 1 in fine). Powoływanie członków Rady z klucza partyjnego stało się utrwaloną od lat praktyką działania politycznego. Skoro w obecnym stanie prawnym nie ma żadnych kryteriów merytorycznych w zakresie powoływania członków Krajowej Rady, pozostają więc de facto wyłącznie kryteria polityczne.

Zgodnie z art. 215 Konstytucji ustawa o radiofonii i telewizji miała określić zasady i tryb działania Rady, jej organizację oraz szczegółowe zasady powoływania jej członków. Okazało się jednak, że niektóre zapisy ustawy medialnej nie zawsze pozostawały w zgodzie z Konstytucją. Dotyczy to zwłaszcza art. 8 ust. 3 pkt 1 ustawy, który umożliwiał zawieszenie członkostwa w partiach politycznych na czas kadencji w Radzie. Ostatecznie przepis ten został uchylony wyrokiem Trybunału Konstytucyjnego z 10 kwietnia 2002 r. (K26/00) z dniem 15 maja 2002 r. $^{53}$

53 Art. 8 ust. 3 pkt 1 ustawy z dnia 29 XII 1992 r. o radiofonii i telewizji (Dz. U. z 2001 r. Nr 101, poz. 1114 iz 2002 r. Nr 25, poz. 253) jest niezgodny z art. 214 ust. 2 Konstytucji Rzeczypospolitej Polskiej - Wyrok Trybunału Konstytucyjnego z dnia 10 kwietnia 2002 r., sygn. akt K 26/00, OTK-A 2002/2/18. 
Jak pisze Izabela Dobosz, wyrok ten wywołał liczne kontrowersje, był m.in. przedmiotem sporu pomiędzy Rzecznikiem Praw Obywatelskich a Prokuratorem Generalnym. W opinii Rzecznika apolityczność nie musi prowadzić do apartyjności. Innego zdania był Prokurator Generalny. Stwierdził, że przynależność do określonej partii jest faktycznym uzewnętrznieniem pogladów politycznych $i$ zaprzeczeniem apolityczności. Jednakże oba organy były zgodne, że zawieszenie członkostwa w partii nie jest tym samym co konstytucyjny zakaz przynależności do partii. Trybunał Konstytucyjny podzielił to stanowisko ${ }^{54}$.

2) Konsekwencją trybu powoływania członków Krajowej Rady Radiofonii i Telewizji jest odpowiedzialność polityczna instytucji regulacyjnej w sektorze audiowizualnym wobec naczelnych organów państwa: Sejmu, Senatu i Prezydenta RP, którym Krajowa Rada zgodnie z ustawą o radiofonii i telewizji składa roczne sprawozdanie ze swej działalności wraz z informacją o podstawowych problemach radiofonii i telewizji. Dokumenty te stanowią następnie przedmiot debaty parlamentarnej, której rezultat przesądza o udzieleniu wotum zaufania Radzie. W przypadku odrzucenia sprawozdania przez obie izby parlamentu i potwierdzenia tego przez Prezydenta RP kadencja wszystkich członków Rady zgodnie z art. 12 ust. 5 wygasa w ciągu 14 dni. Przyjęcie bądź odrzucenie sprawozdania Krajowej Rady przez parlament jest więc rezultatem politycznego kompromisu, którego efektem jest udzielenie lub pozbawienie Rady kredytu politycznego zaufania.

3) Przewodniczący KRRiT z mocy swoich szczególnych ustawowych uprawnień wynikających z treści art. 10 ust. 2-6 ustawy o radiofonii i telewizji pozostaje pod szczególną polityczną presją, gdyż w procesie kontroli działalności nadawców wyposażony jest m.in. w możliwość nakładania sankcji finansowych, co de facto czyni Radę organem podejmującym działania o charakterze cenzury represyjnej.

4) Wobec braku inicjatywy ustawodawczej udział Rady w projektowaniu z Prezesem Rady Ministrów kierunków polityki państwa w dziedzinie radiofonii i telewizji jest wyrazem politycznej dyspozycyjności Rady wobec działań kolejnych rządów kształtujących własną politykę medialną. „Stanie na straży wolności słowa” odbywa się więc stosownie do zaleceń politycznego decydenta, czego dowodem jest także model finansowania Rady z budżetu państwa, zgodnie z art. 11 ust. 3 ustawy o radiofonii i telewizji.

5) Szczególną kontrolę polityczną Rada sprawuje wobec nadawców publicznych. Dotyczy to zwłaszcza przeprowadzania jawnych i otwartych konkursów na stanowiska cztonków rad nadzorczych $w$ jednostkach publicznej radiofonii $i$ telewizji (art. 6 ust. 2 pkt 11 ustawy o radiofonii i telewizji). Rady Nadzorcze spółek Telewizja Polska SA i Polskie Radio SA liczą po siedmiu członków. Pięciu zostaje wyłonionych w konkursie przeprowadzonym przez Krajową Radę spośród kandydatów posiadających kompetencje w dziedzinie prawa, finansów, kultury oraz mediów, zgłoszonych przez organy kolegialne uczelni akademickich. Jednego powołuje minister właściwy ds. kultury i ochrony dziedzictwa narodowego, jednego członka Rady Nadzorczej powołuje też minister właściwy ds. skarbu państwa (art. 28. ust. 1).

54 I. Dobosz, Prawo prasowe, s. 119. 
W przypadku spółek radiofonii regionalnej, które w odróżnieniu od oddziałów terenowych Telewizji Polskiej SA posiadają osobowość prawną, rady nadzorcze liczą pięciu członków, z których czterech zostaje wyłonionych w konkursie przeprowadzonym przez Krajową Radę spośród kandydatów posiadających identyczne kompetencje i zgłoszonych przez organy kolegialne uczelni akademickich działające w danym regionie oraz jednego powołanego wspólnie przez ministra właściwego ds. skarbu państwa i ministra właściwego ds. kultury i ochrony dziedzictwa narodowego (art. 28 ust. 1a). Kadencja rady nadzorczej trwa trzy lata, na czele rady stoi wybrany przez nią przewodniczący.

6) Także zarządy spółek nadawców publicznych, liczące od jednego do trzech członków, powoływane są uchwałą Krajowej Rady Radiofonii i Telewizji na wniosek rady nadzorczej. Odwoływani są na wniosek rady nadzorczej lub walnego zgromadzenia, którym jest minister właściwy ds. skarbu państwa ${ }^{55}$. W 2010 r. zmieniono dotychczasowe rozwiązanie, zgodnie z którym członków zarządu, w tym prezesa Telewizji Polskiej SA lub prezesa Polskiego Radia SA, mogła odwołać wyłącznie rada nadzorcza i to w specjalnym trybie - większością kwalifikowaną. Obecny kształt ustawy medialnej pozwala więc rządowi bezpośrednio wpływać na obsadę kluczowych stanowisk w spółkach mediów publicznych.

7) Z nominacji Krajowej Rady Radiofonii i Telewizji pochodzą również członkowie rad programowych nadawców publicznych, będące organami opiniodawczo-doradczymi zarządów spółek radiofonii i telewizji. Liczą one piętnastu członków powoływanych przez KRRiT na cztery lata. Dziesięciu spośród nich reprezentuje ugrupowania parlamentarne. Pozostałych pięciu, będący w mniejszości, to „fachowcy", powoływani z grona osób legitymujących się dorobkiem i doświadczeniem w sferze kultury i mediów. O zawartości programów publicznej radiofonii i telewizji decydują jednak nie fachowcy, a politycy reprezentujacy spoteczne interesy i oczekiwania zwiazane $z$ dziatalnościa programowa spótki (art. 28a ust. 2 ustawy o radiofonii i telewizji). KRRiT ustala wysokość diet przysługujacych członkom rad programowych, a zarządy spółek radiofonii i telewizji świadczą im pomoc organizacyjną i finansową. Skoro politycy zasiadający w radach programowych z reguły nie są ekspertami w sprawach mediów, często badania dotyczące oceny poziomu i jakości emitowanych programów zleca się firmom zewnętrznym, co znacznie zwiększa koszty działalności rad programowych.

Są więc to gremia w największym stopniu uzależnione od polityków, posiadające ustawowe uprawnienia dokonywania oceny jakości programów nadawców publicznych. Podejmują bowiem uchwały w sprawach programowych, które następnie są przedmiotem „obrad i postanowień” rad nadzorczych, zgodnie z art. 368 i 370 kodeksu spółek handlowych. Mimo iż uchwały rad programowych nie mają charakteru wiążącego, w praktyce mogą nawet przyczynić się do odwołania zarządu spółek radiofonii i telewizji. Rady programowe, oprócz głównej siedziby spółek Telewizja Polska SA i Polskie Radio SA w Warszawie, działają także w każdej ze spółek radiofonii regional-

55 Art. 27 został zmieniony Ustawą z dnia 6 sierpnia 2010 r. o zmianie ustawy o radiofonii i telewizji oraz ustawy o opłatach abonamentowych, Dz. U.2010, nr 152, poz. 1023. 
nej oraz w każdym oddziale terenowym telewizji publicznej. Osobną radę programową ma również TV Polonia.

8) Krajowa Rada Radiofonii i Telewizji rozlicza też nadawców publicznych z ich ustawowych obowiązków w zakresie informowania o życiu politycznym kraju. Dotyczy to zwłaszcza wypełniania przez nadawców publicznych obowiązków wynikających z treści art. 22 ustawy i radiofonii i telewizji, a mianowicie umożliwiania naczelnym organom państwa bezpośredniej prezentacji i wyjaśniania polityki państwa, a także art. 23, obligującego jednostki publicznej radiofonii i telewizji do stwarzania partiom politycznym możliwości przedstawiania stanowisk w węzłowych sprawach publicznych. Rada, wydając w tych sprawach stosowne rozporządzenia, nadzoruje więc działalność nadawców publicznych w zakresie wykonywania przez nich „misji” ${ }^{6}$. Dotyczy to zarówno relacjonowania na antenie obrad Sejmu i Senatu, rozpowszechniania programów informacyjnych i publicystycznych z udziałem polityków, jak i realizacji na antenie nadawców publicznych prawa partii politycznych, związków zawodowych i zwiazków pracodawców do przedstawiania stanowisk w węzłowych sprawach publicznych. Telewizja Polska SA i Polskie Radio SA zobowiązane są zgodnie z rozporzadzeniem KRRiT z 3 grudnia 2009 r. do składania Radzie kwartalnych sprawozdań uwzględniających tytuły audycji przedstawiających stanowiska partii politycznych, czas ich trwania, nazwę partii, związku zawodowego czy związku pracodawców z dokładnym podaniem czasu wystąpień na antenie ich przedstawicieli. Ponadto Krajowa Rada rozlicza nadawców publicznych z realizacji obowiązku udostępniania anteny politykom w czasie kampanii wyborczych, w zakresie emisji bezpłatnych audycji wyborczych oraz płatnych ogłoszeń wyborczych.

\section{BIBLIOGRAFIA}

Chruściak R., Konstytucjonalizacja wolności mediów, wolności wypowiedzi oraz Krajowej Rady Radiofonii i Telewizji. Ksztattowanie przepisów konstytucyjnych i ustawowych, Warszawa 2004, Z Prac Instytutu Nauk Politycznych, 10. Studia nad Polityka, 11.

Debata „Media publiczne - nowy ład”, Fundacja Batorego, 20 IV 2009, [online] http://www. batory.org.pl/programy_operacyjne/debaty/2009/media_publiczne_nowy_lad.

Dobosz I., Prawo prasowe, Warszawa 2011, Seria Akademicka Wolters Kluwer Polska.

Dyrektywa Parlamentu Europejskiego i Rady 2010/13/UE z dnia 10 marca 2010 r. w sprawie koordynacji niektórych przepisów ustawowych, wykonawczych $i$ administracyjnych państw czton-

56 Rozporządzenie Krajowej Rady Radiofonii i Telewizji z dnia 21 sierpnia 1996 r. w sprawie trybu postępowania w związku z prezentowaniem i wyjaśnianiem w publicznej radiofonii i telewizji polityki państwa przez naczelne organy państwowe, Dz. U. 1996, nr 109, poz. 526, oraz ujednolicona treść Rozporządzenia Krajowej Rady Radiofonii i Telewizji z dnia 24 kwietnia 2003 r. w sprawie trybu postępowania $\mathrm{w}$ związku z przedstawianiem $\mathrm{w}$ programach publicznej radiofonii i telewizji stanowisk partii politycznych, związków zawodowych i związków pracodawców w węzłowych sprawach publicznych, Dz. U. 2003, nr 75, poz. 679; t.j. Dz. U. 2009, nr 222, poz. 1774, które weszło w życie 29 III 2010. 
kowskich dotyczacych świadczenia audiowizualnych ustug medialnych (dyrektywa o audiowizualnych ustugach medialnych), Dz. U. UE L 95, 15 IV 2010.

Garlicki L., Polskie prawo konstytucyjne. Zarys wyktadu, wyd. 9, Warszawa 2005.

Komisja Europejska, Komunikat Komisji do Parlamentu Europejskiego, Rady, Komitetu Ekonomiczno-Spotecznego oraz Komitetu Regionów - Biata księga nt. ustug użyteczności publicznej, Bruksela, 12.5.2004, COM(2004) 374 wersja ostateczna.

Komisja Europejska, Komunikat Komisji w sprawie stosowania zasad pomocy państwa wobec radiofonii i telewizji publicznej, Dz. U. UE C 257/1, 27 X 2009.

Konstytucja RP z dnia 2 kwietnia 1997 r., Dz. U. 1997, nr 78, poz. 483.

Krajowa Rada Radiofonii i Telewizji, Biata księga „Polityka państwa polskiego w dziedzinie mediów elektronicznych w kontekście europejskiej polityki audiowizualnej - zatożenia nowej ustawy o mediach elektronicznych", Warszawa 2004.

Krajowa Rada Radiofonii i Telewizji, Dziatalność Krajowej Rady Radiofonii i Telewizji w zakresie wprowadzania naziemnej telewizji cyfrowej w Polsce, Warszawa 2006.

Krajowa Rada Radiofonii i Telewizji, Obrona lokalności i demokracji lokalnej. Strategia dziatania Krajowej Rady Radiofonii i Telewizji na rzecz ochrony lokalnego charakteru i pluralizmu oferty programowej w lokalnych mediach elektronicznych, Warszawa 2005.

Krajowa Rada Radiofonii i Telewizji, Strategia Państwa Polskiego $w$ dziedzinie mediów elektronicznych na lata 2005-2020, Warszawa 2005.

Krajowa Rada Radiofonii i Telewizji, Strategia regulacyjna na lata 2011-2013, Warszawa 2011.

Krajowa Rada Radiofonii i Telewizji, Zielona ksiega „Polityka państwa polskiego w dziedzinie mediów elektronicznych w kontekście europejskiejpolityki audiowizualnej-zatożenia nowej ustawy o mediach elektronicznych", Warszawa 2003.

Kublik A., Telewizja twórców gotowa, Wyborcza.pl, 4 III 2010, [online] http://wyborcza. pl/1,76842,7623630,Telewizja_tworcow_gotowa.html.

Matlak A., Radiofonia i telewizja, [w:] Prawo mediów, red. J. Barta, R. Markiewicz, A. Matlak, Warszawa 2005.

Media Diversity in Europe, Media Division, Directorate General of Human Rights, Strasbourg 2002.

Miżejewski M., Transformacja telewizji w Polsce po roku 1989 na tle zmian politycznych, Przemyśl 2005.

Plan wdrażania telewizji cyfrowej w Polsce, Warszawa, 4 VI 2010, [online] http://static.cyfryzacja.gov.pl/files/documenty/PlanDTTwersja221042010RMRCL.pdf.

Projekt ustawy o zadaniach publicznych $w$ dziedzinie ustug medialnych, Sejm Rzeczypospolitej Polskiej, druk nr 1847, Warszawa, 18 III 2009.

Pytanie o media, Wiara.pl, 14 V 2010, [online] http://info.wiara.pl/doc/521755.Pytanie-o-media.

Rozporzadzenia Krajowej Rady Radiofonii i Telewizji z dnia 24 kwietnia 2003 r. w sprawie trybu postępowania $w$ zwiazku $z$ przedstawianiem $w$ programach publicznej radiofonii i telewizji stanowisk partii politycznych, zwiąków zawodowych i zwiazków pracodawców w weztowych sprawach publicznych, Dz. U. 2003, nr 75, poz. 679; t.j. Dz. U. 2009, nr 222, poz. 1774. 
Rozporzadzenie Krajowej Rady Radiofonii i Telewizji z dnia 21 sierpnia $1996 r$. w sprawie trybu postępowania w zwiazku z prezentowaniem i wyjaśnianiem w publicznej radiofonii i telewizji polityki państwa przez naczelne organy państwowe, Dz. U. 1996, nr 109, poz. 526.

Rozporzadzenie Rady (WE) nr 139/2004 z dnia 20 stycznia 2004 r. w sprawie kontroli koncentracji przedsiębiorstw, Dz. U. UE L 24, 29 I 2004.

Rozporzadzenie Rady Ministrów z dnia 29 czerwca 2005 r. w sprawie Krajowej Tablicy Przeznaczeń Częstotliwości, Dz. U. 2005, nr 134, poz. 1127 z późn. zm.

Sarnecki P., Regulacja problematyki środków spotecznego przekazu w Konstytucji Rzeczypospolitej Polskiej, [w:] Prawo mediów, red. J. Barta, R. Markiewicz, A. Matlak, Warszawa 2005.

Stanowisko KRRiT, dotyczace poselskiego projektu ustawy o zmianie ustawy o radiofonii i telewizji i innych ustaw, zawartego w druku sejmowym nr 151, przekazane Marszatkowi Sejmu RP 21 stycznia 2008 roku, [online] http://www.krrit.gov.pl/dla-mediow-i-analitykow/publikacje/ stanowiska/2008/.

Uchwata Trybunatu Konstytucyjnego z dnia 10 maja 1994 r., sygn. akt W. 7/94.

Ustawa z dnia 14 czerwca 1960 r. Kodeks postępowania administracyjnego, Dz. U. 2000, nr 98, poz. $1071 \mathrm{z}$ późn. $\mathrm{zm}$.

Ustawa z dnia 16 kwietnia 1993 r. o zwalczaniu nieuczciwej konkurencji, t.j. Dz. U. 2003, nr 153, poz. 1503 z późn. $\mathrm{zm}$.

Ustawa z dnia 16 lipca 2004 r. Prawo telekomunikacyjne, Dz. U. 2004, nr 171, poz. 1800 z późn. zm.

Ustawa z dnia 16 lutego 2007 r. o ochronie konkurencji i konsumentów, Dz. U. 2007, nr 50, poz. 331 .

Ustawa z dnia 25 kwietnia 2006 r. o zmianie ustawy o radiofonii i telewizji, Dz. U. 2006, $\mathrm{nr} 83$, poz. 574 .

Ustawa z dnia 29 grudnia 1992 r. o radiofonii i telewizji, t.j. Dz. U. 2004, nr 253, poz. 2531 z późn. zm.

Ustawa $z$ dnia 29 grudnia 2005 r. o przeksztatceniach i zmianach w podziale zadań i kompetencji organów państwowych wtaściwych w sprawach tączności, radiofonii i telewizji, Dz. U. 2005, nr 267, poz. 2258.

Ustawa z dnia 30 czerwca 2011 r. o wdrożeniu naziemnej telewizji cyfrowej, Dz. U. 2011, nr 153, poz. 903.

Ustawa $z$ dnia 6 sierpnia 2010 r. o zmianie ustawy o radiofonii i telewizji oraz ustawy o optatach abonamentowych, Dz. U. 2010, nr 152, poz. 1023.

Wyrok Trybunatu Konstytucyjnego z dnia 10 kwietnia 2002 r., sygn. akt K 26/00, OTK-A 2002/2/18.

Wyrok Trybunatu Konstytucyjnego z dnia 23 marca 2006 r., sygn. akt K 4/06, OTK ZU 2006, nr 3A, poz. 32 .

Zielona księga „Pluralizm $i$ koncentracja mediów $w$ ramach rynku wewnętrznego - ocena potrzeb dziatania na szczeblu Wspólnotowym", Bruksela, 23.12.1992, COM(92) 480. 
Dr Maciej MIŻEJEWSKI - adiunkt w Zakładzie Dziennikarstwa Instytutu Nauk Politycznych i Stosunków Międzynarodowych UJ. W latach 1992-2000 dziennikarz Działu Programów Informacyjnych Telewizji Polskiej SA oddział w Krakowie. Stypendysta Università degli Studi di Pavia we Włoszech. Wykładowca Uniwersytetu Papieskiego Jana Pawła II w Krakowie. Autor dwóch monografii: Transformacja telewizji w Polsce po roku 1989 na tle zmian politycznych (Przemyśl 2005) oraz Ochrona pluralizmu w polityce medialnej Wtoch (Kraków 2013), a także artykułów naukowych w dziedzinie polityki medialnej, m.in.: Polityczne konsekwencje nowelizacji ustawy o radiofonii i telewizji, „Universitas” 2003, nr 27-28; Il sistema radiotelevisivo polacco sullo sfondo delle trasformazioni politiche "Nomos. Le attualità nel diritto” 2004, nr 2; Kryptoreklama a praktyka dziennikarska, [w:] Media a demokracja, red. L. Pokrzycka, W. Mich, Lublin 2007; The Profession of Journalist in Poland and its Legal Aspects, „Newsletter” (Jagiellonian University) 2008, nr 35; Polish Media in a New European Dimension, „Newsletter” (Jagiellonian University) 2008, nr 36; Finansowanie mediów publicznych w polityce medialnej Unii Europejskiej. Przyktad Polski, Wegier, Francji i Niemiec, „Politeja” 2013, nr 23; Media i polityka we Wtoszech, „Politeja” 2013, nr 25; Wolność mediów a odpowiedzialność za stowo w debacie publicznej, „Studia Socialia Cracoviensia” 2014, Vol. 6, nr 1. 